\title{
Structure of Cost and Returns in Maize Production under Different Supply Chains in Northern and Southern Karnataka, India
}

\author{
Vivekanand Prabhuraj Patil* and K. Mahendran \\ Department of Arm, TNAU, Coimbatore-641003, Tamil Nadu, India \\ *Corresponding author
}

\begin{tabular}{|l|}
\hline Ke y w o r d s \\
Maize Production, \\
Davangere and \\
Chitradurga
\end{tabular}

\section{A B S T R A C T}

The study was undertaken with an objective to quantify the comparative economics of Maize, under different supply chains in Northern and Southern Karnataka. A sample of 240 farmers was selected using random sampling method and the data was collected through personal interview method. Tabular analysis was employed for analysing the data. Northern and Southern Karnataka were purposively selected for their major contribution to Maize production. Among the Northern districts, Belagavi and Haveri and in Southern districts Davangere and Chitradurga had the highest area and production. Results indicated that among the supply chains existed in two regions, per hectare cost of cultivation of maize was higher in Northern Karnataka, share of variable cost to the total cost was also higher in the case of Northern Karnataka followed by Southern Karnataka. The Northern Karnataka farmers realized relatively higher levels of net returns due to higher price received for the produce and better management practices. The B; C ratio was higher in Northern Karnataka (1.93) followed by Southern Karnataka (1.71) and as the share of total variable cost to the total cost was higher. Further the net returns per hectare in case of Northern Karnataka and Southern Karnataka was estimated to be Rs. 48,605.5 and Rs. 29,819 respectively. It was inferred that profitability of maize cultivation was higher in Northern Karnataka than in Southern Karnataka.

\section{Introduction}

Maize starch, an excellent source of carbohydrates, is a highly versatile industrial raw material that finds extensive application in the textile, food, pharmaceutical and paper industries. Maize is preferred as poultry feed because of its easy availability. India is the second-largest egg and third-largest broiler chicken producer in the world (Hellin et al., 2015). In terms of volume, maize constituted about 60 per cent of the poultry feed and therefore was a critical raw material. International maize trade is now larger than the international rice trade. India is one of the beneficiaries of the booming international maize trade. The country exported a record twenty million tonnes of maize in 2016-17, valued at Rs. 35,000 crore (Ministry of Agriculture and farmers Welfare 2017) and is now the fourth-largest maize exporter after the US, Brazil and Ukraine. In the last five years, exports have doubled and by 2025 , maize will be the developing into world's 
largest crop area and it is expected that the demand for maize in the developing world will be doubled by 2050 . It is estimated that nearly one-fourth of the stock in a modern grocery store contain maize in one form or the other. Besides as a food source like maize rich breakfast cereals, cooking oils, snacks and popcorn, to the products like toothpaste, detergent, paper, dyes, soaps to artificial sweeteners, fructose, etc. contain maize in various compositions. Maize also finds application in food containers, plastic food packaging, baby powder, diapers, medicine, vitamin tablets, textile products, candies and so on. Internationally, maize has been processed to produce bio ethanol in a big way for blending with auto fuels. In fact, maize is the only cereal that has such diverse uses.

The total average maize in Northern and Southern districts of Karnataka with 46477, 33513.In Northern Karnataka districts Belagavi and Haveri was having highest in share in the area of maize Belagavi 133122 ha, Haveri 128598 ha. In Southern Karnataka districts Davanagere and Chitradurga was having highest in share in the area of maize Davanagere 160336, Chitradurga 70286.Were in the production districts among Northern and Southern districts of Karnataka were having highest in share in the production of maize are Haveri 530474 tonnes, Belagavi 390529 tonnes, and Haveri 458848 tonnes, Chitradurga 153129. There was a minimal production from Karnataka of Bengaluru 2756 tonnes, Bidar 2318 tonnes, Raichur 1720 tonnes, Udapi 56 tonnes, Dakshina Kannada 13 tonnes respectively.

\section{Materials and Methods}

\section{Data collection}

For the study, Sample farmers were selected based on simple random sampling. The total sample comprised of 120 maize farmers each from Northern and Southern Karnataka. Sixty commission agents were selected purposively from four districts of Northern and Southern Karnataka. Sixty Traders were selected purposively from the sample study area.

Twenty processing units were selected purposively from Belagavi, Haveri, Chitradurga and Davanagere districts of Karnataka, and Twenty Maize processors from both selected Northern and Southern Karnataka. The respondents were contacted in person with a comprehensive pre-tested interview schedule and required information was collected from them during April2018.

\section{Partial budgeting}

In order to compute the costs and returns in maize among Northern and Southern Karnataka, partial budgeting techniques was employed.

\section{Cost of cultivation}

To estimate the costs and returns from cultivation of Maize, it is necessary to know about the concepts. The various concepts used were presented below for better understanding.

\section{Costs}

The total costs were divided into two broad classes

Variable cost

Fixed cost

\section{Variable costs}

Land Preparation: Cost incurred for preparing land to sow seeds like ploughing, harrowing and covering of seeds.

Seed: Cost of seed purchased per hectare. 
FYM and Fertilizers: Cost of chemicals and Fertilizers actually paid by farmers.

Weeding: cost of the weeding per hectare.

Plant protection chemicals (PPC): Cost incurred in the purchase of plant protection chemicals.

Harvesting and threshing: Cost incurred for harvesting and threshing and miscellaneous charges were taken.

Interest on Working Capital: This was calculated on the entire working cost of the enterprise at the rate of interest of 12 per cent per annum.

\section{Fixed costs}

Interest on fixed Capital: This was calculated on the entire fixed cost of the enterprise at the rate of interest @6.25 per cent per annum.

\section{Total cost of cultivation}

Cost of cultivation included variable and fixed costs.

Cost of production per quintal: it was calculated by dividing the total cost of cultivation per hectare by the yield obtained per hectare of Maize.

\section{Returns}

Gross returns: Gross returns were computed on the basis of actual prices multiplied by the maize product and byproduct yield. Net returns: It was calculated by deducting total cost from total returns

\section{Price spread analysis}

Price spread in general, is referred to as the difference between price paid by the consumer and the price received by the farmers for an equivalent unit of the product.

Price spread $=$. $($ Consumer price - Price received by the farmer)

\section{Farmer's share in consumer rupee (\%)}

Further, the farmer's share in consumer rupee was calculated with the help of the following formula.

$F s=(F p / C p) X 100$

Where,

$\mathrm{Fs}=$ Farmer's share in consumer rupee $(\%)$

$\mathrm{Fp}=$ Farmer's price

$\mathrm{Cp}=$ Consumer's price

\section{Results and Discussion}

\section{Cost of cultivation}

Detailed information on cost and returns of maize production incurred by farmers are given Table 1.

Economics of maize cultivation is highly essential from supply chain point of view. Because more profitability would further strengthen the linkages between supply chain agents. In Northern Karnataka total cost worked out to be Rs.52,351/ha which was higher than Southern Karnataka (Rs.42,106/ha). Among total cost of cultivation in both the regions variable cost was higher (Rs.45,976/ha (87.82\%) in North Karnataka) and Rs. 37,856/ha (89.91 \%) in Southern Karnataka.

In Northern Karnataka majority of variable cost was incurred on FYM and fertilizers (Rs.16,000/ha) followed by seeds and sowing, harvesting and threshing, land preparation, interest on fixed capital at 12 per cent, 
weeding and plant protection chemicals, whereas in Southern Karnataka majority of variable cost was incurred on FYM and fertilizers, seeds and sowing, harvesting and threshing, land preparation, interest on working capital at 12 per cent, weeding and plant protection chemicals.

The fixed cost accounted for 11.46 per cent and 0.72 per cent in Northern Karnataka for rental value on land and interest on fixed capital respectively. In case of Southern Karnataka, the rental value on land $(9.50 \%)$ and interest on fixed capital $(0.59 \%)$ formed the fixed cost component. The share of fixed cost to the total cost was higher in share of Northern Karnataka.

The gross returns by the sale of main product as well as by product in Northern Karnataka and Southern Karnataka was estimated to be Rs.1,00,956.5 and Rs.71,925 respectively. Further the net returns per hectare in case of Northern Karnataka and Southern Karnataka was estimated to be Rs.48,605.5 and Rs.29,819 respectively. Finally, the benefit to cost ratio was arrived and it was found to be 1.93 and 1.71 in case of Northern Karnataka and Southern Karnataka respectively.

Hence it could be inferred that profitability of maize cultivation was higher in Northern Karnataka than in Southern Karnataka. This was also the major factor that influenced more farmers in Northern Karnataka to take up maize cultivation. As a consequence, more industries were set up related to maize due to the assurance of supply of better raw materials for industrial purpose.

\section{Price spread of maize in Northern and Southern Karnataka}

Detailed information on price spread of maize in Northern and Southern Karnataka are given in Table 2.

\section{Price spread of maize in Northern and} Southern Karnataka

The price paid at the farm gate for the assessment of the price spread for Northern and Southern Karnataka respectively was taken as Rs.1553 per quintal and Rs.1430 per quintal. The final price paid by the consumer on an average was Rs.2480.15 and Rs.2169 respectively for Northern and Southern Karnataka. This range is being taken as a bench mark to determine the price spread across the channel.

There is no marketing cost and margin as there was no marketing activities at farmers' level of Northern and Southern Karnataka. The total marketing cost was worked out for commission agent as Rs.35/Q, Rs.108.33/Q was incurred at the traders level and Rs.337.08/Q was incurred at the processing level. The marketing cost at the commission agent level of Northern and Southern Karnataka included packing charges which had the highest share of Rs.15 per quintal and Rs.15 per quintal followed by loading and unloading charges of Rs.10/Q, and Rs.7/Q, weighing charges Rs.3/kg and miscellaneous charges (Rs.7/Q).

The marketing cost at the trader's level included transportation charges which had the highest share with Rs.75/Q, and Rs.40/Q followed by labour charges of Rs.5.83/Q and Rs.5/Qas APMC charges 1.5 per cent @ Rs.19.5/Q and Rs.18/Q Miscellaneous charges Rs.8/Q and Rs.5/Q for Northern and Southern Karnataka respectively. The marketing cost at the processor level included transportation charges which had the highest share with Rs.85/Q, and Rs.90/Q followed by electricity charge Rs.2.5/Q, and Rs.3.2/Q, labour charge with Rs.6.25/Q and Rs.7/Q and processing cost of Rs.100/Q and Rs.85/Q for Northern and Southern Karnataka respectively. 
Table.1 Cost of cultivation of maize (Rs/ha)

\begin{tabular}{|c|c|c|c|c|c|}
\hline \multirow[t]{2}{*}{$\begin{array}{l}\text { SI. } \\
\text { No }\end{array}$} & \multirow[t]{2}{*}{ Particulars } & \multicolumn{2}{|c|}{$\begin{array}{l}\text { Northern } \\
\text { Karnataka }\end{array}$} & \multicolumn{2}{|c|}{$\begin{array}{c}\text { Southern } \\
\text { Karnataka }\end{array}$} \\
\hline & & Cost & $\%$ & Cost & $\%$ \\
\hline \multirow[t]{9}{*}{ I } & \multicolumn{5}{|l|}{ Variable cost / Material Cost } \\
\hline & Land preparation & 5000 & 9.55 & 4500 & 10.69 \\
\hline & Seed and sowing & 11750 & 22.44 & 9800 & 23.27 \\
\hline & FYM \& Fertilizers & 16000 & 30.56 & 13000 & 30.87 \\
\hline & Weeding & 2000 & 3.82 & 1000 & 2.37 \\
\hline & Plant Protection chemicals & 1200 & 2.29 & 1000 & 2.37 \\
\hline & Harvesting and thrashing & 5100 & 9.74 & 4500 & 10.69 \\
\hline & Interest on working capital @ 12\% & 4926 & 9.40 & 4056 & 9.63 \\
\hline & Total variable cost & 45,976 & 87.82 & 37,856 & 89.91 \\
\hline \multirow[t]{4}{*}{ II } & \multicolumn{5}{|l|}{ Fixed Cost } \\
\hline & Rental value on land & 6000 & 11.46 & 4000 & 9.50 \\
\hline & Interest on fixed capital @ 6\% & 375 & 0.72 & 250 & 0.59 \\
\hline & Total Fixed cost & 6375 & 12.18 & 4250 & 10.09 \\
\hline III & Total cost of Cultivation & 52,351 & 100 & 42,106 & 100 \\
\hline \multirow[t]{7}{*}{ IV } & \multicolumn{5}{|l|}{ Gross Returns } \\
\hline & Main Product $(\mathrm{Q})$ & 60.50 & & 47.50 & \\
\hline & By Product (Q) & 140 & & 110 & \\
\hline & $\begin{array}{l}\text { value of main product } \\
\text { @ Rs. } 1553 \text { / Q - Northern } \\
\text { Karnataka } \\
\text { @ Rs. 1430 / Q - Southern } \\
\text { Karnataka }\end{array}$ & 93956.50 & & 67925 & \\
\hline & $\begin{array}{l}\text { value of by product } \\
\text { @ Rs. } 50 \text { / Q - Northern Karnataka } \\
@ \text { Rs. } 36 \text { / Q - Southern Karnataka }\end{array}$ & 7000 & & 4000 & \\
\hline & Gross Returns (Rs.) & 100956.50 & & 71925 & \\
\hline & Net returns (Rs.) & 48605.50 & & 29819 & \\
\hline V & B:C Ratio & 1.93 & & 1.71 & \\
\hline
\end{tabular}


Table.2 Price spread of maize in Northern and Southern Karnataka

\begin{tabular}{|c|c|c|c|c|c|}
\hline \multirow{3}{*}{$\begin{array}{l}\text { SI. } \\
\text { No }\end{array}$} & \multirow{3}{*}{ Particulars } & \multirow{2}{*}{\multicolumn{2}{|c|}{ Northern Karnataka }} & \multirow{2}{*}{\multicolumn{2}{|c|}{\begin{tabular}{c|c|} 
(Rs/q) \\
Southern Karnataka
\end{tabular}}} \\
\hline & & & & & \\
\hline & & $\begin{array}{c}\text { Price } \\
\text { (Rs./q) }\end{array}$ & $\%$ & $\begin{array}{l}\text { Price } \\
\text { (Rs./q) }\end{array}$ & $\%$ \\
\hline & \multicolumn{5}{|l|}{ Farmer } \\
\hline \multirow[t]{2}{*}{1} & Price received by the farmers & 1553 & & 1430 & \\
\hline & \multicolumn{5}{|l|}{ Commission Agent } \\
\hline 4 & Purchase price & 1553 & & 1430 & \\
\hline \multirow[t]{5}{*}{5} & \multicolumn{5}{|l|}{ Marketing cost } \\
\hline & \begin{tabular}{l|l} 
A & Packing cost
\end{tabular} & 15 & 4.45 & 15 & 5.26 \\
\hline & B Loading and unloading & 10 & 2.97 & 7 & 2.45 \\
\hline & Weighing charges & 3 & 0.89 & 3 & 1.05 \\
\hline & D Miscellaneous & 7 & 2.08 & 7 & 2.45 \\
\hline I & Marketingcost $(a+b+c+d)$ & 35 & 10.38 & 32 & 11.22 \\
\hline \multirow[t]{2}{*}{6} & Marketing margin & 52 & & 38 & \\
\hline & \multicolumn{5}{|l|}{ Traders } \\
\hline 7 & Purchase price & 1640 & & 1500 & \\
\hline \multirow[t]{5}{*}{8} & \multicolumn{5}{|l|}{ Marketing Cost } \\
\hline & A $\quad$ Transportation & 75 & 22.25 & 40 & 14.03 \\
\hline & Labour cost & 5.83 & 1.73 & 5 & 1.75 \\
\hline & C $\quad$ APMC charges @ $1.5 \%$ & 19.5 & 5.78 & 18 & 6.31 \\
\hline & D Miscellaneous & 8 & 2.37 & 5 & 1.75 \\
\hline II & Marketing cost $(a+b+c+d)$ & 108.33 & 32.14 & 68 & 23.84 \\
\hline \multirow[t]{2}{*}{9} & Marketing margin & 185.67 & & 123 & \\
\hline & \multicolumn{5}{|l|}{ Processing Unit } \\
\hline 10 & Purchase price & 1934 & & 1691 & \\
\hline \multirow[t]{5}{*}{11} & \multicolumn{5}{|l|}{ Marketing cost } \\
\hline & A Transportation charges & 85 & 25.22 & 90 & 31.56 \\
\hline & B Electricity cost charges & 2.5 & 0.74 & 3.2 & 1.12 \\
\hline & Labour cost charges & 6.25 & 1.85 & 7 & 2.45 \\
\hline & D Processing cost & 100 & 29.67 & 85 & 29.80 \\
\hline \multirow[t]{2}{*}{ III } & Total cost $(a+b+c+d)$ & 193.75 & 57.48 & 185.2 & 64.94 \\
\hline & Totalcost Marketing(I+II+III) & 337.08 & 100.00 & 285.2 & 100.00 \\
\hline 12 & Sales price & 2480.15 & & 2169.54 & \\
\hline 13 & Marketing margin & 352.4 & & 293.34 & \\
\hline 14 & Price paid by the consumer & 2480.15 & & 2169.54 & \\
\hline 15 & Price Spread & 927.15 & & 739.54 & \\
\hline 16 & Farmers share in consumer rupee & 62.62 & & 65.91 & \\
\hline
\end{tabular}

Note: Figures in the parenthesis indicate percent to each column total. 
The total marketing margin of the supply chain in Northern and Southern Karnataka was Rs.538.07/Q and Rs.416.34/Q where the processing units had the lions share with Rs. 352.4/Q and the traders with Rs.108.33/Q and Rs.68/Q. The farmer's share in consumer's rupee was 62.62 per cent and 65.91 per cent in the maize supply chain prevalent in Northern and Southern Karnataka.

The price spread was worked out for the above said channel which indicated that the price spread was Rs.927.15 per quintal, and Rs.739.54 per quintal of maize for Northern and Southern Karnataka respectively. There is direct relationship in terms of proportions attributed to marketing margins and marketing cost with price spread. It means that as the price spread increased the proportion of marketing margin and cost decreased.

\section{Cost of cultivation}

The cost and returns of the maize production in Northern and Southern Karnataka per hectare was analysed and the average total annual cost was worked out to Rs.52,352 per hectare and Rs.42,106 per hectare respectively, out of which Rs.45,976 (87.82 per cent), Rs.37,856 (89.91) was incurred as total annual variable cost while Rs.6,375 (12.18 per cent), Rs.4,250 (10.09) was total annual fixed cost. The mean production of maize was worked out to 60.5 quintals and 47.5 quintals per hectare. The average gross returns per hectare was Rs.1,00,956.5 and Rs.71,925. The average market price of maize in Northern and Southern Karnataka was Rs.1553 per quintal and Rs.1430 per quintal. The average net return received by the farmer per hectare was Rs. 48,605.5 and 29,819. Further, for every rupee of investment in maize production
Rs.1.93 and Rs.1.71 was obtained as returns by the Northern and Southern Karnataka farmers.

\section{Price spread of maize supply chain in Northern and Southern Karnataka}

The price paid at the farm gate in Northern and southern Karnataka was Rs.1553 per quintal, Rs. 1430 per quintal and the final price paid by the consumer was on an average Rs.2480.15, Rs.2169.54. The price spread was worked out for the channel indicated in Northern and Southern Karnataka as Rs.927 per quintal, Rs.739.54 per quintal of maize. The overall average total cost of farmer, commission agent, traders, processing units were worked out Northern and Southern Karnataka Rs.337.08 and Rs.285.2. The farmers received Rs.1553, Rs.1430 (62.62 per cent) (65.91 per cent) as share in consumer rupee.

\section{References}

Kumar, N., and Singh, S. (2005). A Study on Price Spread, Marketing Costs and Margins of Inland Fish in Haryana State. Agricultural Marketing-Delhi-, 48(2), 40.

Kumar, N., and Singh, S. (2005). A Study on Price Spread, Marketing Costs and Margins of Inland Fish in Haryana State. Agricultural Marketing-Delhi-, 48(2), 40.

Ladaniya, M., Wanjari, V., and Mahalle, B. C. (2003). Price spread of pomegranate. Indian Journal of Agricultural Economics, 58(4), 800.

Sharma, R. (2011). Behaviour of market arrivals and prices of tomato in selected markets of north India. International Journal of Farm Sciences, 1(1), 69-74.

\section{How to cite this article:}

Vivekanand Prabhuraj Patil and Mahendran, K. 2019. Structure of Cost and Returns in Maize Production under Different Supply Chains in Northern and Southern Karnataka, India. Int.J.Curr.Microbiol.App.Sci. 8(06): 2483-2489. doi: https://doi.org/10.20546/ijcmas.2019.806.297 